\title{
Fabrication of Hydrophobic Coatings Using Sugarcane Bagasse Waste Ash as Silica Source
}

\author{
Sriharan Natarajan ${ }^{1}$, Senthil Thottipalayam Subramaniyam ${ }^{1, *}$ and Vignesh Kumaravel ${ }^{2, *}$ (D) \\ 1 Department of Physics, Erode Sengunthar Engineering College, Erode 638057, India; \\ sriharan.prabu88@gmail.com \\ 2 Department of Environmental Science, Institute of Technology Sligo, Ash Lane, Co.Sligo F91 YW50, Ireland \\ * Correspondence: tssenthi@gmail.com (S.T.S.); Kumaravel.Vignesh@itsligo.ie (V.K.)
}

Received: 2 December 2018; Accepted: 2 January 2019; Published: 7 January 2019

Featured Application: The results of this research work would be beneficial to develop hydrophobic building materials to avoid fungus contamination.

\begin{abstract}
Eco-friendly hydrophobic coatings were fabricated on tiles via the drop-casting process. Sugarcane bagasse waste ash (SBA) was used as a silica source and dimethyldiethoxysilane (DMDEOS) was used as a surface functionalizing agent. The elemental composition of SBA was measured using X-ray fluorescence (XRF) and energy-dispersive spectroscopy (EDS) techniques. The surface morphology of SBA was analyzed through the field-emission scanning electron microscopy (FESEM) technique. The surface wettability of SBA coated tiles was evaluated by determining the static water contact angle (WCA). XRF studies showed that the impurities were removed, and the silica content was enriched by the acid treatment. SBA coated tiles showed good hydrophobicity with a WCA of $135^{\circ}$. The high hydrophobicity of the coated tiles may be attributed to the increase of surface roughness by SBA. Moreover, the SBA coating was successfully tested on various substrates such as tiles, brick, glass, and cotton cloth. SBA coated glass substrate was more durable compared to other substrates at normal room temperature.
\end{abstract}

Keywords: hydrophobicity; self-cleaning; coating; water contact angle; tiles

\section{Introduction}

In recent years, solid waste management strategies have mainly focused on recycling rather than on waste disposal or storage. Industrial activities generate large quantities of various types of wastes, this causes significant economic and environmental problems, and management of industrial waste in an economic and ecological way has become a matter of great global interest. As a result, the use of waste materials can minimize the cost associated with landfilling [1,2]. Sugarcane is one of the largest crops in the world. It is grown on approximately 25 million hectares, in over 90 countries, with a world harvest of 1.75 billion tons. World sugar demand is the main driving force behind sugarcane farming. Cane represents $80 \%$ of the sugar produced; most of the rest is made up of sugar beet. India is the second largest sugarcane producer in the world and the sugarcane production rate is increasing every year [3]. Sugarcane bagasse (SB) is a waste produced in sugar industries after the extraction of sugar cane juice. There is a large volume of sugarcane bagasse produced all over the world, which implies the importance of approaches to the elimination of the material. Chemical analyses have shown that the ash obtained by burning the bagasse (sugarcane bagasse ash (SBA)) is rich in silica $\left(\mathrm{SiO}_{2}\right)$ content. The quantity of silica content in SBA varies depending on the surrounding environment, nature of the soil, the harvest period, and the process involved. The concentration of silica increases with the increase in the amount of bagasse ash from the sugar cane [4-6]. 
Generally, the surface wettability can be characterized by the water contact angle (WCA). In the last two decades, special wettability with multifunctional surfaces has aroused great interest in fundamental research and industrial applications [7-13]. A surface with a drop of water below $90^{\circ}$ and above $90^{\circ}$ of WCA is commonly referred to as hydrophilic and hydrophobic surfaces, respectively. Precise superhydrophobic surfaces with a WCA above $150^{\circ}$ have attracted significant attention due to their unique anti-humidifying and self-cleaning properties for practical applications. It is known that there are plants and numerous creatures in nature with incredible superhydrophobic surfaces. For example, the hydrophobic properties of lotus leaf with micro and nanoscopic surface architectures [14-16] have attracted much interest in industry and academia. The principle of water repellence of a superhydrophobic surface can be extended to practical applications, for example to develop coatings for car windows, buildings, tiles, and clothes [17-25]. Today, superhydrophobic materials have found spectacular advantages such as water repellence [26,27], oil recovery [28-30], self-cleaning [31,32], anti-corrosive [33,34], anti-blocking [35-37], mechanical strength [38,39], anti-icing [40,41], and so on. Various techniques have been established to fabricate superhydrophobic surfaces, such as plasma or laser etching [42,43], photolithography [14,44], and electrochemical deposition [45]. However, these methods employ complicated processes, requiring specific equipment, rigorous preparation conditions, special substrates, and expensive/toxic fluoro silanes. In recent years, the fabrication of hydrophobic surfaces using waste materials and carbonaceous films has received significant attention [46-51]. Silica could be extracted from rice husk ash [46,47], oil palm fuel ash [12], and paper waste sludge ash [48,49] to fabricate various hydrophobic substrates. Moreover, this would be highly beneficial for the waste disposal problems.

The main objective of this present study was to investigate the application of SBA and non- fluoro silanes to fabricate hydrophobic surfaces. The hydrophobic surface was fabricated by the drop casting technique on various materials like floor tiles, brick, glass substrate, and cotton fabric. The morphology and chemical composition of SBA was analyzed by FESEM, EDS, and XRF analysis.

\section{Experimental}

\subsection{Preparation of SBA Coating Solution}

All the chemicals used were of analytical grade and they were used as received without further purification. Deionized water (DW) was used in the experiments. Sugarcane bagasse (SB) was collected from the sugarcane waste in agricultural lands, Erode, Tamilnadu, India. SB was pyrolyzed in a muffle furnace at $500{ }^{\circ} \mathrm{C}$ and $750{ }^{\circ} \mathrm{C}$ for $2 \mathrm{~h}$ with a heating rate of $10{ }^{\circ} \mathrm{C} / \mathrm{min}$. The resultant SBA was sieved to remove the impurities. Silica was extracted from SBA as sodium silicate by heat treatment with $\mathrm{NaOH}$. It was further converted into silica solution (SS) through the reaction with mineral acid. An amount of $20 \mathrm{~g}$ of SBA was heated in $200 \mathrm{~mL}$ of $1 \mathrm{M} \mathrm{NaOH}$ at $80^{\circ} \mathrm{C}$ for $1 \mathrm{~h}$ under magnetic stirring. After that, the suspension was cooled and filtered by a Whatman filter paper. The resultant sodium silicate solution was treated with sulfuric acid $\left(\mathrm{H}_{2} \mathrm{SO}_{4}\right)$ to obtain SS [12,47]. The coating solution (SS and surface functionalizing agent mixture) was prepared via acidic hydrolysis of SS in a mixture of dimethydiethoxylsilane (DMDEOS) and deionized water. An amount of $10 \mathrm{~mL}$ of SS (at various $\mathrm{pH}$ such as $3,5,7$, and 10) was added into a mixture of $35 \mathrm{~mL}$ isopropanol, $1 \mathrm{~mL}$ of $0.1 \mathrm{M} \mathrm{H}_{2} \mathrm{SO}_{4}$, and $4 \mathrm{~mL}$ DW under magnetic stirring at room temperature for $30 \mathrm{~min}$ (solution A). Then $15 \mathrm{~mL}$ of DMDEOS, $30 \mathrm{~mL}$ of isoproponal, $1 \mathrm{~mL}$ of $0.1 \mathrm{M} \mathrm{H}_{2} \mathrm{SO}_{4}$, and $4 \mathrm{~mL}$ of DW was stirred for $30 \mathrm{~min}$ (solution $\mathrm{B}$ ). Solution $\mathrm{B}$ was added dropwise to solution $\mathrm{A}$ under constant stirring. The whole mixture was stirred at room temperature for $48 \mathrm{~h}$ (SBA coating solution).

\subsection{Fabrication of Hydrophobic Surfaces}

The substrates such as floor tiles, brick, glass and cotton fabric $\left(10 \times 10 \mathrm{~cm}^{2}\right)$ were cleaned by sonification for $5 \mathrm{~min}$ each in water and ethanol to remove the impurities. The cleaned substrates were 
dried at $80^{\circ} \mathrm{C}$ for $1 \mathrm{~h}$ in an air oven. SBA coating solution was applied on the cleaned substrates by the drop-casting technique. The coated substrates were dried at $80^{\circ} \mathrm{C}$ for $1 \mathrm{~h}$ in an air oven.

\subsection{Characterization:}

The surface morphology, top-view and the fracture cross section were observed by a field emission scanning electron microscope (FE-SEM: SIGMA HV—Carl Zeiss with Bruker Quantax 200-Z10 EDS Detector). The elemental composition was confirmed using X-ray fluorescence (XRF) and energy dispersive spectroscopy (EDS) techniques. WCA measurements were carried out with the help of an FTA 188 video tensiometer instrument. WCA values were determined after $5 \mathrm{~s}$ when the de-ionized water drop of $6 \mu \mathrm{L}$ began to be still on the samples. WCA values were averaged from five measurements at different positions on the same substrate.

\section{Results and Discussion}

The morphology and elemental composition of SBA was thoroughly analyzed by FESEM, EDS and XRF techniques. The hydrophobicity of SBA coated substrates was measured via WCA analysis.

\subsection{Field-Emission Scanning Electron Microscopy (FESEM)}

Figure 1a-d portrays the FESEM images of SBA annealed at $500{ }^{\circ} \mathrm{C}$ (Figure $1 \mathrm{a}, \mathrm{b}$ ) and $750{ }^{\circ} \mathrm{C}$ (Figure 1c,d). Figure 1a,c shows that most of the SBA particles are in fibrous shape and few porous particles are also observed at low magnification. Figure $1 b, d$ represent the irregular rectangular shape particles and flat-faced spherical particles at high magnification. It was previously reported that the fibrous particles were generally carbon, while the rectangular shaped particles were silica and the spherical particles were aluminosilicates [52,53]. Meanwhile, smaller particles appearing with irregular surfaces are ascribed to the elimination of organic substances from SBA which left the inorganic fraction, such as silica and potassium. The control of the crystalline phases of SBA could be useful to improve the pozzolanic activity [54]. Silica is the main cause of pozzolanic reactivity in an amorphous SBA phase. Therefore, the sugarcane was calcined in the range of $400-800{ }^{\circ} \mathrm{C}$. It was also found that the most important weight loss was observed in this range due to organic matter. In another study, the SBA was obtained between $550{ }^{\circ} \mathrm{C}$ and $700{ }^{\circ} \mathrm{C}$, which resulted in spongy particles because the calcination temperature was lower than the melting point of SBA [55]. In addition to the temperature variation, the duration of the ignition was another variable parameter that was studied. 

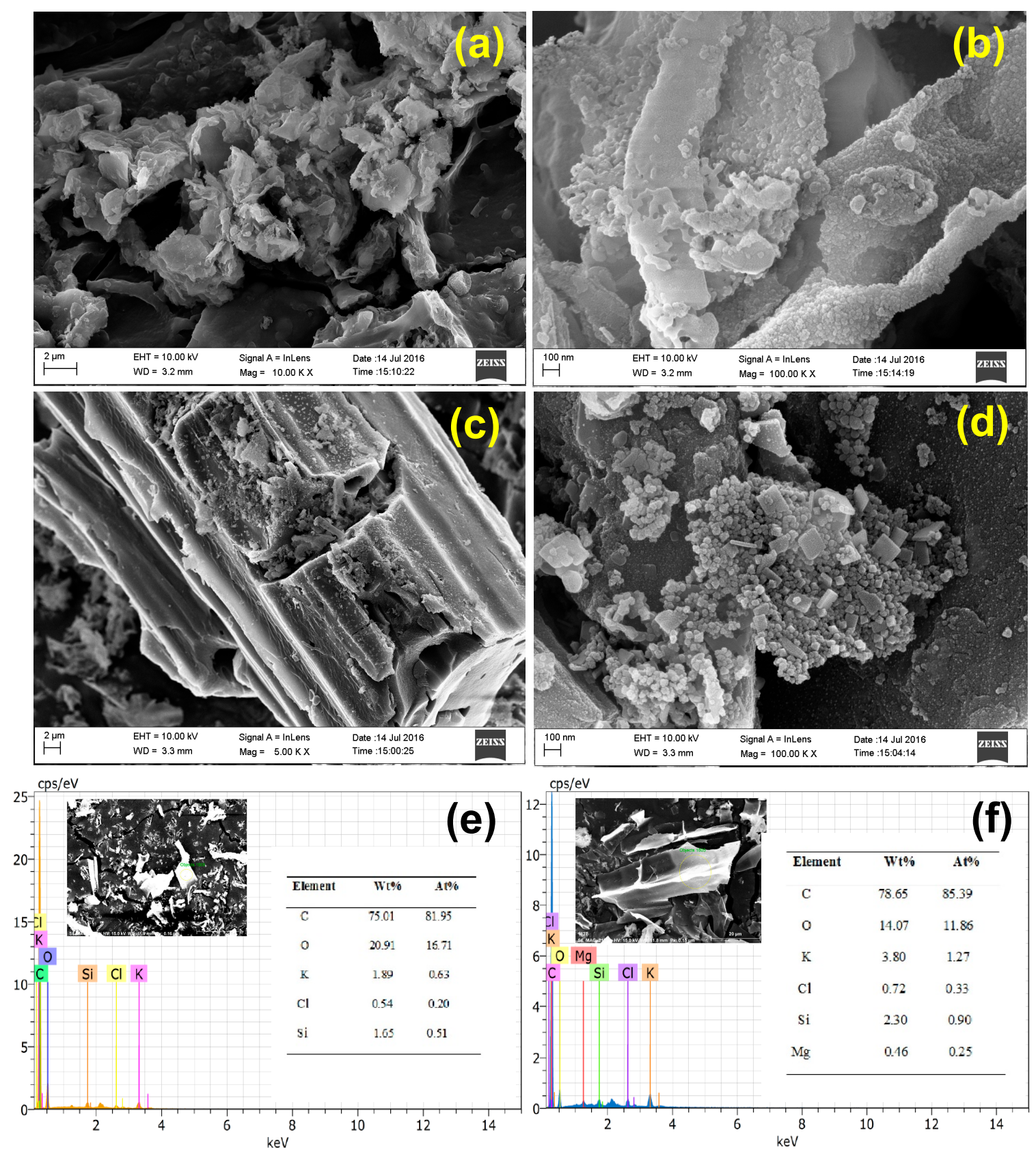

Figure 1. FESEM images of (a) sugarcane bagasse ash (SBA) annealed at $500{ }^{\circ} \mathrm{C}(\mathbf{b}) \mathrm{SBA}$ annealed at $750{ }^{\circ} \mathrm{C}$ (c) magnified FESEM image of SBA at $500{ }^{\circ} \mathrm{C}$ (d) magnified FESEM image of SBA at $750{ }^{\circ} \mathrm{C}$ (e) EDS spectrum of SBA annealed at $500{ }^{\circ} \mathrm{C}$ (f) EDS spectrum of SBA annealed at $750{ }^{\circ} \mathrm{C}$. The inset is elemental presentation values tabulated corresponding to images respectively.

\subsection{Energy Dispersive Spectroscopy (EDS)}

Figure 1e,f displays the inset FESEM images of SBA samples. The lighter parts are probably due to potassium and silicon, providing a chemical contrast because they are more sensitive to the detector. On the other hand, the darker parts contain carbon and oxygen, as detected by the EDS analysis [56]. As noted, the main elements of activated carbon are carbon and oxygen. Secondly, silicon and potassium elements predominate in significant amounts in the ash. The presence of $\mathrm{C}, \mathrm{O}$, $\mathrm{K}, \mathrm{Cl}$, and $\mathrm{Si}$ without any impurities are confirmed from Figure $1 \mathrm{e} . \mathrm{SBA}-500{ }^{\circ} \mathrm{C}$ has a composition of $\mathrm{C}-75.0 \mathrm{wt} \%, \mathrm{O}-20.9 \mathrm{wt} \%, \mathrm{~K}-1.89 \mathrm{wt} \%, \mathrm{Cl}-0.54 \mathrm{wt} \%$ and $\mathrm{Si}-1.65 \mathrm{wt} \%$. SBA-750 ${ }^{\circ} \mathrm{C}$ mainly contains $\mathrm{C}, \mathrm{O}, \mathrm{K}, \mathrm{Cl}, \mathrm{Si}$, and $\mathrm{Mg}$ elements with a composition of $\mathrm{C}-78.6 \mathrm{wt} \%, \mathrm{O}-14.0 \mathrm{wt} \%, \mathrm{~K}-3.80$ 
$\mathrm{wt}^{\mathrm{t}} \%, \mathrm{Cl}-0.72 \mathrm{wt} \%, \mathrm{Si}-2.30 \mathrm{wt} \%$ and $\mathrm{Mg}-0.46 \mathrm{wt} \% . \mathrm{SiO}_{2}$ content was further analyzed in detail by XRF.

\subsection{X-Ray Fluorescent Spectroscopy (XRF)}

Table 1 displays the chemical composition of elements present in the raw SBA, acid treated SBA- $500{ }^{\circ} \mathrm{C}$ and acid treated SBA- $750{ }^{\circ} \mathrm{C}$. The elements such as $\mathrm{Si}, \mathrm{Ca}, \mathrm{S}, \mathrm{Al}, \mathrm{K}, \mathrm{Mg}, \mathrm{P}, \mathrm{Fe}, \mathrm{Ti}, \mathrm{Mn}$, and $\mathrm{Cu}$ exist in the three samples. The composition of $\mathrm{SiO}_{2}$ in acid treated $\mathrm{SBA}$ samples $\left(\mathrm{SBA}-500{ }^{\circ} \mathrm{C}=\right.$ $88 \%$; SBA- $750{ }^{\circ} \mathrm{C}=94 \%$ ) is higher compared to raw SBA (54\%), suggesting acid treatment is beneficial to eliminate the impurities from SBA [57]. It is also observed that the $\mathrm{SiO}_{2}$ content is increased on increasing the calcination temperature. XRF study shows that acid treatment is a necessary post treatment process to remove impurities and obtain a pure $\mathrm{SiO}_{2}$ composition for subsequent use.

Table 1. Elemental composition of raw sugarcane bagasse ash (SBA), acid treated SBA- $500{ }^{\circ} \mathrm{C}$ and acid treated SBA- $750{ }^{\circ} \mathrm{C}$.

\begin{tabular}{cccc}
\hline & \multicolumn{3}{c}{ Weight $\%$} \\
\hline \multirow{2}{*}{ Components } & Raw Sample & After Acid Treatment & After Acid Treatment \\
\cline { 3 - 4 } & & SBA $\mathbf{5 0 0}{ }^{\circ} \mathbf{C}$ & SBA 750 ${ }^{\circ} \mathbf{C}$ \\
\hline $\mathrm{SiO}_{2}$ & 54.20 & 87.63 & 94.2 \\
$\mathrm{CaO}$ & 3.77 & 1.26 & 2.16 \\
$\mathrm{SO}_{3}$ & 16.10 & 0.45 & 1.34 \\
$\mathrm{Al}_{2} \mathrm{O}_{3}$ & 0.20 & 0.40 & 0.94 \\
$\mathrm{~K}_{2} \mathrm{O}$ & 1.26 & 0.28 & 0.41 \\
$\mathrm{MgO}$ & 20.72 & 0.19 & 0.39 \\
$\mathrm{P}_{2} \mathrm{O}_{5}$ & 7.36 & 0.07 & 0.20 \\
$\mathrm{Fe}_{2} \mathrm{O}_{3}$ & 0.78 & 0.06 & 0.11 \\
$\mathrm{TiO}_{2}$ & 0.01 & 0.01 & 0.03 \\
$\mathrm{MnO}_{\mathrm{CuO}}$ & 1.45 & - & 0.01 \\
\end{tabular}

\subsection{Water Contact Angle Test}

The floor tiles coated with acid treated SBA-750 ${ }^{\circ} \mathrm{C}$ showed the best hydrophobicity. This is ascribed to the increase of surface roughness and maximum silica content. The high surface roughness imparts a tortuous three-phase contact line, which increases the hydrophobicity of the floor tiles. The wettability of the SBA coated surfaces was assessed in terms of WCA. SBA coated floor tiles (Figure 2a-d) show a WCA of $135^{\circ}, 105^{\circ}, 124^{\circ}$, and $93^{\circ}$ for $\mathrm{pH} 3,5,7$, and 10 solutions, respectively. SBA solution with $\mathrm{pH} 3$ showed a high WCA compared to others. SBA with enriched $\mathrm{SiO}_{2}$ and long alkyl chain of DMDEOS influence the surface roughness and reduce the surface energy of the floor. 


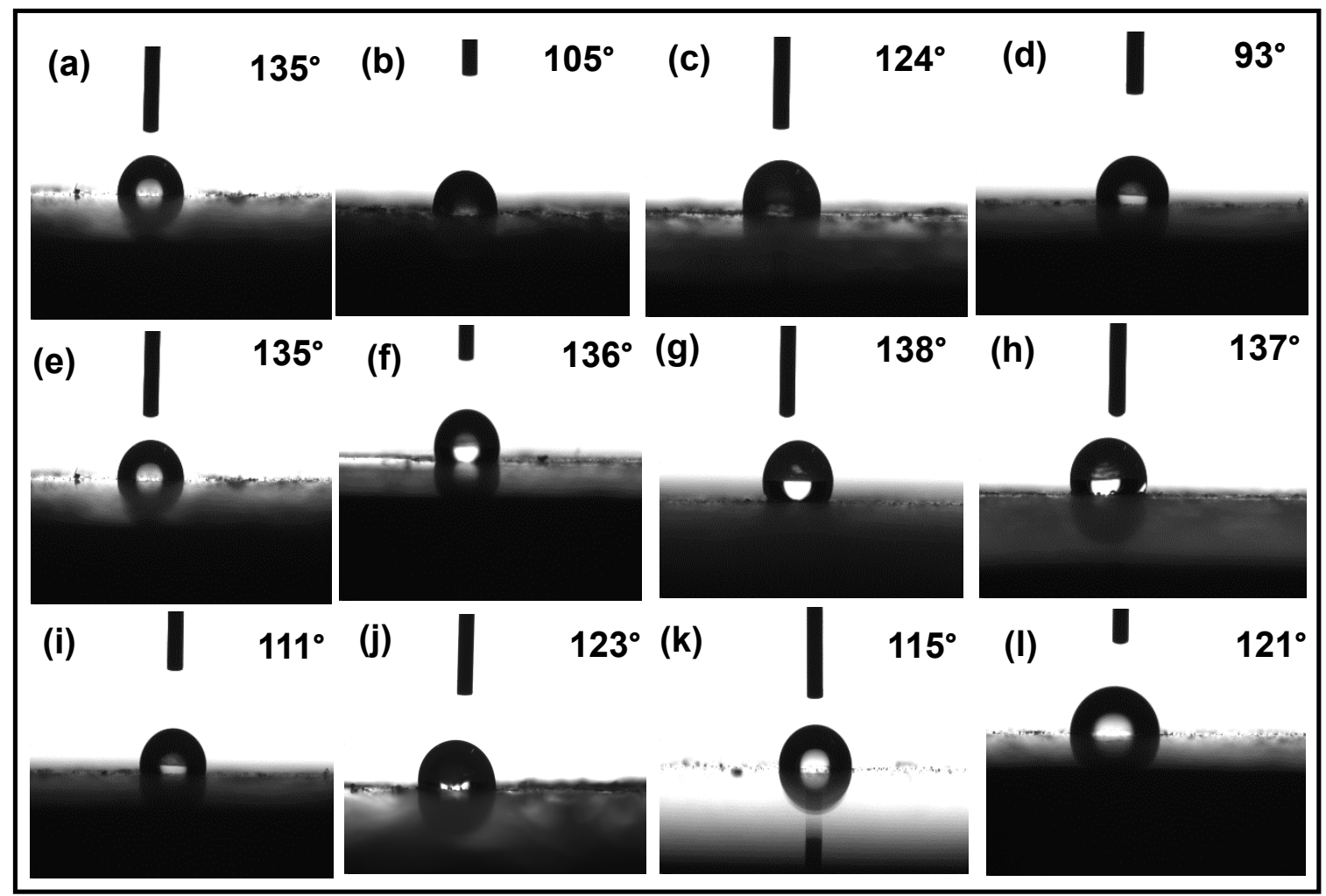

Figure 2. Photographs of water droplets on SBA coated floor tiles at (a) $\mathrm{pH} 3$, (b) $\mathrm{pH}$ 5, (c) $\mathrm{pH}$ 7, (d) $\mathrm{pH}$ 10. Water contact angle (WCA) of SBA coated substrates (e) tiles, (f) brick, (g) glass, (h) cotton fabric. WCA of SBA coated substrates after 30 days under open air conditions (i) tiles, (j) brick, (k) glass, and (1) cotton fabric.

According to the principle of wettability of the surface [12,13], the coating composition on the surface of tiles, which consisted of silica and low surface free energy DMDEOS, could effectively prevent the water penetration. Therefore, the treated floor tiles were highly hydrophobic. SBA mixture with $\mathrm{pH} 3$ was further tested on various substrates such as brick, glass, and cotton fabric. The WCA of SBA coated tiles, brick, glass and cotton fabric are $135^{\circ}, 136^{\circ}, 138^{\circ}$, and $137^{\circ}$, respectively. Almost all of the SBA coated substrates showed good hydrophobicity. The substrates were kept at open air conditions (RTP) and the WCA was measured after 30 days (Figure 2i-1) to evaluate the stability of the coating. The WCAs of SBA coated tiles, brick, glass and cotton fabric are $111^{\circ}, 123^{\circ}, 115^{\circ}$ and $121^{\circ}$, respectively. These results revealed that a single layer of SBA coating is not enough for long-term usage. This could be rectified by increasing the number of coating layers on the substrates.

\section{Summary and Outlook}

In this study, we successfully developed a simple drop-casting approach to produce a hydrophobic coating on various surfaces such as tiles, bricks, glass and cotton fabrics. The WCAs of SBA coated floor tiles, bricks, glass, and cloths are $135^{\circ}, 136^{\circ}, 138^{\circ}$, and $137^{\circ}$, respectively. The hydrophobicity of the substrates coated with SBA can be attributed to the increase of surface roughness induced by silica and DMDEOS. In general, it has been shown that SBA coating using a drop-casting process is a promising approach to producing highly hydrophobic surfaces in static materials.

The future work on SBA coatings should be focused on the mechanism of hydrophobicity, water tilt angle, contact angle hysteresis, chemical stability, UV durability, and optical transmittance for commercial applications. The hydrophobicity of SBA coatings would be improved (more than $150^{\circ}$ ) by the addition of polymeric silanes (e.g., polydimethylsiloxane (PDMS)). Moreover, the addition 
of photocatalytic nanoparticles in the SBA coating solution would be beneficial to impart antimicrobial properties for indoor building materials such as brick and tiles.

Author Contributions: Conceptualization, methodology and design, V.K.; Investigation, data creation, data analysis and manuscript draft preparation S.N.; Supervision, S.T.S. and V.K.; Writing-Review and Editing, V.K.

Funding: This work was supported by grant no. 34/14/49/2014-BRNS with ATC from the Board of Research in Nuclear Sciences (BRNS) innovation major project proposal of the Department of Atomic Energy (DAE), Government of India.

Acknowledgments: The authors are grateful to the Management of Erode Sengunthar Engineering College for providing the necessary laboratory facilities.

Conflicts of Interest: The authors declare no conflicts of interest.

\section{References}

1. Laurent, A.; Bakas, I.; Clavreul, J.; Bernstad, A.; Niero, M.; Gentil, E.; Hauschild, M.Z.; Christensen, T.H. Review of LCA studies of solid waste management systems-Part I: Lessons learned and perspectives. Waste Manag. 2014, 34, 573-588. [CrossRef] [PubMed]

2. Lima, S.A.; Sales, A.; Almeida, F.d.C.R.; Moretti, J.P.; Portella, K.F. Concretes made with sugarcane bagasse ash: Evaluation of the durability for carbonation and abrasion tests. Ambient. Constr. 2011, 11, 201-212. [CrossRef]

3. Khan, S.; Kamal, M.; Haroon, M. Potential of cement-treated sugar cane bagasse ash (SCBA) as highway construction material. Road Trans. Res. 2015, 24, 35-43.

4. Arumugam, A.; Ponnusami, V. Modified SBA-15 synthesized using sugarcane leaf ash for nickel adsorption. Indian J. Chem. Technol. 2013, 20, 101-105.

5. Drummond, A.-R.F.; Drummond, I.W.; Research, E.C. Pyrolysis of sugar cane bagasse in a wire-mesh reactor. Ind. Eng. Chem. Res. 1996, 35, 1263-1268. [CrossRef]

6. Rauf, N.; Damayanti, M.; Pratama, S.W.I. The influence of sugarcane bagasse ash as fly ash on cement quality. AIP Conf. Proc. 2017, 1801, 040009.

7. Karim, A.M.; Rothstein, J.P.; Kavehpour, H.P. Experimental study of dynamic contact angles on rough hydrophobic surfaces. J. Colloid Interface Sci. 2018, 513, 658-665. [CrossRef]

8. Kumar, M.; Kulkarni, M.A.; Chembu, N.G.; Banpurkar, A.; Kumaraswamy, G. Aqueous dispersions of lipid nanoparticles wet hydrophobic and superhydrophobic surfaces. Soft Matter. 2018, 14, 205-215. [CrossRef]

9. Samanta, T.; Bagchi, B. Temperature effects on the hydrophobic force between two graphene-like surfaces in liquid water. J. Chem. Sci. 2018, 130, 29. [CrossRef]

10. Park, M.-H.; Ha, J.-H.; Song, H.; Bae, J.; Park, S.-H. Enhanced adhesion properties of conductive super-hydrophobic surfaces by using zirco-aluminate coupling agent. J. Ind. Eng. Chem. 2018, 68, 387-392. [CrossRef]

11. Li, X.-P.; Sun, Y.-L.; Luo, C.-W.; Chao, Z.-S. UV-resistant hydrophobic $\mathrm{CeO}_{2}$ nanomaterial with photocatalytic depollution performance. Ceram. Int. 2018, 44, 13439-13443. [CrossRef]

12. Saharudin, K.A.; Sreekantan, S.; Basiron, N.; Chun, L.K.; Kumaravel, V.; Abdullah, T.K.; Ahmad, Z.A. Improved super-hydrophobicity of eco-friendly coating from palm oil fuel ash (POFA) waste. Surf. Coat. Technol. 2018, 337, 126-135. [CrossRef]

13. Basiron, N.; Sreekantan, S.; Saharudin, K.A.; Ahmad, Z.A.; Kumaravel, V. Improved Adhesion of Nonfluorinated ZnO Nanotriangle Superhydrophobic Layer on Glass Surface by Spray-Coating Method. J. Nanomater. 2018, 2018, 7824827. [CrossRef]

14. Fürstner, R.; Barthlott, W.; Neinhuis, C.; Walzel, P. Wetting and self-cleaning properties of artificial superhydrophobic surfaces. Langmuir 2005, 21, 956-961. [CrossRef]

15. Marmur, A. The lotus effect: Superhydrophobicity and metastability. Langmuir 2004, 20, 3517-3519. [CrossRef]

16. Gao, L.; McCarthy, T.J. The "lotus effect" explained: Two reasons why two length scales of topography are important. Langmuir 2006, 22, 2966-2967. [CrossRef] [PubMed] 
17. Kichigina, G.A.; Kushch, P.P.; Krivonogova, E.A.; Kiryukhin, D.P.; Dorohov, V.G.; Barelko, V.V. Tetrafluoroethylene Telomeres Used to Prepare Fluorine-Containing Hydrophobic Silica Fabric. Inorg. Mater. Appl. Res. 2018, 9, 861-867. [CrossRef]

18. Zulfiqar, U.; Awais, M.; Hussain, S.Z.; Hussain, I.; Husain, S.W.; Subhani, T. Durable and self-healing superhydrophobic surfaces for building materials. Mater. Lett. 2017, 192, 56-59. [CrossRef]

19. Alfieri, I.; Lorenzi, A.; Ranzenigo, L.; Lazzarini, L.; Predieri, G.; Lottici, P.P. Synthesis and characterization of photocatalytic hydrophobic hybrid $\mathrm{TiO}_{2}-\mathrm{SiO}_{2}$ coatings for building applications. Build. Environ. 2017, 111, 72-79. [CrossRef]

20. Midtdal, K.; Jelle, B.P. Self-cleaning glazing products: A state-of-the-art review and future research pathways. Sol. Energy Mater. Sol. Cells 2013, 109, 126-141. [CrossRef]

21. Cao, M.; Guo, D.; Yu, C.; Li, K.; Liu, M.; Jiang, L. Water-repellent properties of superhydrophobic and lubricant-infused "slippery" surfaces: A brief study on the functions and applications. ACS Appl. Mater. Interfaces 2015, 8, 3615-3623. [CrossRef] [PubMed]

22. Mates, J.E.; Bayer, I.S.; Palumbo, J.M.; Carroll, P.J.; Megaridis, C.M. Extremely stretchable and conductive water-repellent coatings for low-cost ultra-flexible electronics. Nat. Commun. 2015, 6, 8874. [CrossRef] [PubMed]

23. Cai, R.; Glinel, K.; De Smet, D.; Vanneste, M.; Mannu, N.; Kartheuser, B.; Nysten, B.; Jonas, A.M. Environmentally Friendly Super-Water-Repellent Fabrics Prepared from Water-Based Suspensions. ACS Appl. Mater. Interfaces 2018, 10, 15346-15351. [CrossRef]

24. Simpson, J.T.; Hunter, S.R.; Aytug, T. Superhydrophobic materials and coatings: A review. Rep. Prog. Phys. 2015, 78, 086501. [CrossRef] [PubMed]

25. Jin, Q.; Li, X.; Deng, C.; Zhang, Q.; Yi, D.; Wang, X.; Tang, Y.; Wang, Y. Silica nanowires with tunable hydrophobicity for lipase immobilization and biocatalytic membrane assembly. J. Colloid Interface Sci. 2018, 531, 555-563. [CrossRef]

26. Chang, C.-C.; Huang, F.-H.; Chang, H.-H.; Don, T.-M.; Chen, C.-C.; Cheng, L.-P. Preparation of water-resistant antifog hard coatings on plastic substrate. Langmuir 2012, 28, 17193-17201. [CrossRef] [PubMed]

27. Lv, Y.; Yu, X.; Jia, J.; Tu, S.-T.; Yan, J.; Dahlquist, E. Fabrication and characterization of superhydrophobic polypropylene hollow fiber membranes for carbon dioxide absorption. Appl. Energy. 2012, 90, 167-174. [CrossRef]

28. Zheng, C.; Cheng, Y.; Wei, Q.; Li, X.; Zhang, Z. Suspension of surface-modified nano-SiO ${ }_{2}$ in partially hydrolyzed aqueous solution of polyacrylamide for enhanced oil recovery. Colloids Surf. A 2017, 524, 169-177. [CrossRef]

29. Choi, S.K.; Son, H.A.; Kim, H.T.; Kim, J.W. Nanofluid Enhanced Oil Recovery Using Hydrophobically Associative Zwitterionic Polymer-Coated Silica Nanoparticles. Energy Fuels. 2017, 31, 7777-7782. [CrossRef]

30. Liu, F.; Ma, M.; Zang, D.; Gao, Z.; Wang, C. Fabrication of superhydrophobic/superoleophilic cotton for application in the field of water/oil separation. Carbohydr. Polym. 2014, 103, 480-487. [CrossRef]

31. Ding, S.; Xiang, T.; Li, C.; Zheng, S.; Wang, J.; Zhang, M.; Dong, C.; Chan, W. Fabrication of self-cleaning super-hydrophobic nickel/graphene hybrid film with improved corrosion resistance on mild steel. Mater. Design. 2017, 117, 280-288. [CrossRef]

32. Colangiuli, D.; Lettieri, M.; Masieri, M.; Calia, A. Field study in an urban environment of simultaneous self-cleaning and hydrophobic nanosized $\mathrm{TiO}_{2}$-based coatings on stone for the protection of building surface. Sci. Total Environ. 2019, 650, 2919-2930. [CrossRef] [PubMed]

33. Xie, J.; Hu, J.; Lin, X.; Fang, L.; Wu, F.; Liao, X.; Luo, H.; Shi, L. Robust and anti-corrosive $\mathrm{PDMS} / \mathrm{SiO}_{2}$ superhydrophobic coatings fabricated on magnesium alloys with different-sized $\mathrm{SiO}_{2}$ nanoparticles. Appl. Surf. Sci. 2018, 457, 870-880. [CrossRef]

34. Rathnayake, R.M.N.M.; Mantilaka, M.M.M.G.P.G.; Hara, M.; Huang, H.-H.; Wijayasinghe, H.W.M.A.C.; Yoshimura, M.; Pitawala, H.M.T.G.A. Graphite intercalated polyaniline composite with superior anticorrosive and hydrophobic properties, as protective coating material on steel surfaces. Appl. Surf. Sci. 2017, 410, 445-453. [CrossRef]

35. Li, N.; Pranantyo, D.; Kang, E.T.; Wright, D.S.; Luo, H.K. In Situ Self-Assembled Polyoxotitanate Cages on Flexible Cellulosic Substrates: Multifunctional Coating for Hydrophobic, Antibacterial, and UV-Blocking Applications. Adv. Funct. Mater. 2018, 28, 1800345. [CrossRef]

36. Zhou, M.; Xiong, X.; Jiang, B.; Weng, C. Fabrication of high aspect ratio nanopillars and micro/nano combined structures with hydrophobic surface characteristics by injection molding. Appl. Surf. Sci. 2018, 427, 854-860. [CrossRef] 
37. Yang, Z.-H.; Chiu, C.-Y.; Yang, J.-T.; Yeh, J.A. Investigation and application of an ultrahydrophobic hybrid-structured surface with anti-sticking character. J. Micromech. Microeng. 2009, 19, 085022. [CrossRef]

38. Liu, F.; Wang, S.; Zhang, M.; Ma, M.; Wang, C.; Li, J. Improvement of mechanical robustness of the superhydrophobic wood surface by coating PVA/SiO 2 composite polymer. Appl. Surf. Sci. 2013, 280, 686-692. [CrossRef]

39. Zuo, J.; Chung, T.-S.; O’Brien, G.S.; Kosar, W. Hydrophobic/hydrophilic PVDF/Ultem®dual-layer hollow fiber membranes with enhanced mechanical properties for vacuum membrane distillation. J. Membr. Sci. 2017, 523, 103-110. [CrossRef]

40. Ruan, M.; Wang, J.; Liu, Q.; Ma, F.; Yu, Z.; Feng, W.; Chen, Y. Superhydrophobic and anti-icing properties of sol-gel prepared alumina coatings. Rus. J. Non-Ferrous Met. 2016, 57, 638-645. [CrossRef]

41. Kulinich, S.A.; Farhadi, S.; Nose, K.; Du, X.W. Superhydrophobic surfaces: Are they really ice-repellent? Langmuir 2011, 27, 25-29. [CrossRef] [PubMed]

42. Huovinen, E.; Hirvi, J.; Suvanto, M.; Pakkanen, T.A. Micro-micro hierarchy replacing micro-nano hierarchy: A precisely controlled way to produce wear-resistant superhydrophobic polymer surfaces. Langmuir 2012, 28, 14747-14755. [CrossRef] [PubMed]

43. Barshilia, H.C.; Gupta, N. Superhydrophobic polytetrafluoroethylene surfaces with leaf-like micro-protrusions through $\mathrm{Ar}+\mathrm{O}_{2}$ plasma etching process. Vacuum 2014, 99, 42-48. [CrossRef]

44. Martines, E.; Seunarine, K.; Morgan, H.; Gadegaard, N.; Wilkinson, C.D.; Riehle, M.O. Superhydrophobicity and superhydrophilicity of regular nanopatterns. Nano Lett. 2005, 5, 2097-2103. [CrossRef] [PubMed]

45. Haghdoost, A.; Pitchumani, R. Fabricating superhydrophobic surfaces via a two-step electrodeposition technique. Langmuir 2013, 30, 4183-4191. [CrossRef] [PubMed]

46. Husni, H.; Nazari, M.R.; Yee, H.M.; Rohim, R.; Yusuff, A.; Ariff, M.A.M.; Ahmad, N.N.R.; Leo, C.P.; Junaidi, M.U.M. Superhydrophobic rice husk ash coating on concrete. Constr. Build. Mater. 2017, 144, 385-391. [CrossRef]

47. Xu, K.; Sun, Q.; Guo, Y.; Dong, S. Effects of modifiers on the hydrophobicity of $\mathrm{SiO}_{2}$ films from nano-husk ash. Appl. Surf. Sci. 2013, 276, 796-801. [CrossRef]

48. Wong, H.S.; Barakat, R.; Alhilali, A.; Saleh, M.; Cheeseman, C.R. Hydrophobic concrete using waste paper sludge ash. Cem. Concr. Res. 2015, 70, 9-20. [CrossRef]

49. Spathi, C.; Young, N.; Heng, J.Y.Y.; Vandeperre, L.J.M.; Cheeseman, C.R. A simple method for preparing super-hydrophobic powder from paper sludge ash. Mater. Lett. 2015, 142, 80-83. [CrossRef]

50. Bayer, I.S.; Davis, A.J.; Biswas, A. Robust superhydrophobic surfaces from small diffusion flame treatment of hydrophobic polymers. RSC Adv. 2014, 4, 264-268. [CrossRef]

51. Bayer, I.S.; Davis, A.J.; Loth, E.; Steele, A. Water jet resistant superhydrophobic carbonaceous films by flame synthesis and tribocharging. Mater. Today Commun. 2015, 3, 57-68. [CrossRef]

52. Aigbodion, V.S.; Hassan, S.B.; Ause, T.; Nyior, G.B. Potential utilization of solid waste (bagasse ash). Int. J. Miner. Mater. Charact. Eng. 2010, 9, 67-77. [CrossRef]

53. Batra, V.S.; Urbonaite, S.; Svensson, G. Characterization of unburned carbon in bagasse fly ash. Fuel 2008, 87, 2972-2976. [CrossRef]

54. Cordeiro, G.C.; Toledo Filho, R.D.; Tavares, L.M.; Fairbairn, E.M.R. Experimental characterization of binary and ternary blended-cement concretes containing ultrafine residual rice husk and sugar cane bagasse ashes. Constr. Build. Mater. 2012, 29, 641-646. [CrossRef]

55. Chusilp, N.; Jaturapitakkul, C.; Kiattikomol, K. Effects of LOI of ground bagasse ash on the compressive strength and sulfate resistance of mortars. Constr. Build. Mater. 2009, 23, 3523-3531. [CrossRef]

56. Bahurudeen, A.; Kanraj, D.; Dev, V.G.; Santhanam, M. Performance evaluation of sugarcane bagasse ash blended cement in concrete. Cem. Concr. Compos. 2015, 59, 77-88. [CrossRef]

57. Worathanakul, P.; Payubnop, W.; Muangpet, A. Characterization for post-treatment effect of bagasse ash for silica extraction. Int. J. Chem. Mol. Eng. 2009, 3, 398-400.

(C) 2019 by the authors. Licensee MDPI, Basel, Switzerland. This article is an open access article distributed under the terms and conditions of the Creative Commons Attribution (CC BY) license (http:/ / creativecommons.org/licenses/by/4.0/). 